\title{
The Effects of Government Corruption on the Fellow Citizens
}

\author{
Sekou Maiga, Xu Feng Ju \\ Wuhan University of Technology (WHUT), Mafangshan , West Campus ,Post Doctoral \\ Building,china.
}

Sekouma17@yahoo.com

\begin{abstract}
Keywords: Fiscal decentralization; tournament competition; corruption; spatial autoregression model

Abstract: Based on the 1997-2009 China And spatial Autoregressive panel data models, empirical vertical fiscal decentralization effect and transverse trophy competition on local corruption. Results showed that vertical degree of fiscal decentralization may deteriorate local corruption and horizontal trophy competition of corruption among local governments have some effect, but its calming effect is smaller than the deteriorating effect of the vertical decentralization. Accordingly, the direction of China's fiscal decentralization system should be: by perfecting the supervising mechanisms constrain resource allocation powers of the local government from top to bottom, compressed space for rent-seeking corruption of local officials and guide the horizontal trophy competition of local officials, strengthening the inhibitory effects of the promotion of official corruption, improve the inherent power of self-discipline of local officials.
\end{abstract}

\section{Introduction}

Corruption is the system expression of inefficiency in the public sector. The World Bank defines corruption as "the abuse of public power for personal gain." Precisely because of the lack of government compliance, self-interested economic subjects (official) by rent-seeking corruption of seeking personal gain possible. Therefore, in a country where corruption was rampant, corruption rife, its government system, and oversight mechanisms are possible irregularity of system, the low efficiency problem. This may be one of the causes of serious corruption in developing countries than developed countries. As to developing countries like China, official corruption has become an important obstacle to economic and social development. Through the system and norms to curb corruption in the public sector at the local level, become the hot issue of academics and policy makers. In recent years, the outpouring of literature, studying the relationship between fiscal decentralization and local public sector corruption, from the theoretical and empirical answers can pass the fiscal decentralization system arrangement of local Government Act suppressed the purpose of rent-seeking corruption of local officials.

This paper is devoted to empirical testing Chinese-style fiscal decentralization and local public sector corruption. And the existing studies, by constructing spatial econometric model and empirical analysis of the vertical and horizontal separation of powers into a single framework, also studied the vertical financial rights allocation and transverse trophy competition on the local impact of corruption. The remainder of this paper is structured as follows: the second part is variable and data on the third part reporting on empirical modeling and estimation results and finally the basic conclusions.

\section{Variables and Data Illustration}

\subsection{Financial decentralization measurement index}

Chinese financial decentralization has a characteristic of multiple dimensions, choosing a single index cannot reflect all its information. we choose a multidimensional measure index system of fiscal decentralization, covering income rights configuration among Chinese government, apportion of expenditure responsibilities, distribution of transfer payments, budgetary revenues and expenditures, and financial management and various aspects of information, to comprehensively measure China's fiscal decentralization. Specific measures include: autonomous local fiscal revenue 
rate (measures the local fiscal revenue accounted for the proportion of total local fiscal revenue), local proportion of fiscal revenue (measures relative size of the local financial income.

\subsection{Measurement index of corruption}

Choose a desired measure is the primary problem of corruption-related research. An empirical research based on country data, select some corruption index measure of international organizations, such as "Transparency International" provides the CPI index (corruption perception index); the World Bank WBC index (WB Corruption Index); ICRG index provides byPRS Group(International Country Risk guide corruption index). These indices are based on surveys of residents in the microscopic level of corruption in their subjective assessment.Strictly speaking, it does not accurately reflect the objective corruption level of a country. Empirical studies based on a country's domestic data,it's usually choose filing number and other corruption offenses as a measure of corruption (Fishman and Gatti, 2002b).Wu Yiping (2008)used the corruption cases per million people filing numbers to indicate the extent of corruption, the corruption index is superior to mere filing several indicators, because it controls the impact of population size area of the corruption.

$$
\text { Corruption }=\frac{\text { Corruption Case Number }}{\text { Regional Population Quantity }} \times 10000 \times\left(1-\frac{\text { Public Security Organs Expenditure }}{\text { the Total Financial Expenditure }}\right)
$$

\subsection{Other control variables}

\section{(1)The per capita GDP}

We expect higher levels of economic development and income of the area, not only the construction of the system of local Government much more perfect, and people to supervise the Government's ability and willingness is also higher, which acts to curb endemic corruption. GDP and population data are from the calendar year of the China Statistical Yearbook.

(2) The degree of opening up

We have import and export amounted to GDP ratio as an indicator of the degree of opening up. Arikan(2004) said that trade barriers for officials to create a space for rent extraction, so as to provide a favorable environment for the rent-seeking corruption. Higher the degree of opening up, means that the higher the freer trade and less trade barriers, this helps reduce the official rentseeking opportunities. Among them, the import and export data from the calendar year the total China Statistical Yearbook and on a calendar year basis the Yuan/dollar exchange rate (average annual), be converted into RMB-denominated.

(3) Level of education among residents

Generally, higher education level of residents of the area, the flow of information more frequently, and corruption are more likely to be found, the cost of corruption (the punishment of acts of corruption) and easier to understand, which can have a deterrent against potential corruption. Therefore, the higher the level of education, may suppress corrupt practices. Method of calculation of the level of education among residents see Gong Feng and Lu Hongyou (2009), the original data from the calendar year the China Statistical Yearbook and the Statistical Yearbook of China's population.

(4) The rate of urbanization

Government departments and officials are mainly concentrated in urban areas than in rural areas, urban areas is a corruption of "high risk". Therefore, the higher the rate of urbanization in a region, officials expected higher level of corruption. Urbanization rate is equal to the town's permanent population divided by the total population, urban population data comes from the new China 60 years Statistics compendium and the China population Statistical Yearbook of the calendar year. 


\section{Conclusions}

Based on panel data of Chinese province, the purpose of the study was to empirically investigate the impact of vertical fiscal decentralization and transverse trophy competition on local public sector corruption ,by constructing and estimating a spatial econometric model. The results indicate that: (1) The degree of vertical fiscal decentralization higher, the corruption in local public sector more serious. Particularly, the corruption of local officials is more likely to be worsen if financial power is dominated and more funds can be used by them; (2) lateral trophy competition among local governments has certain inhibitory effect on the local public sector corruption, which can't offset the effect of the vertical fiscal decentralization thoroughly. On the whole, the fiscal decentralization in China reduces the efficiency of local government system, which has caused more serious local public sector corruption and behavior.

The policy implication of this paper is that the excessive configuration authority of financial resources shouldn't be blindly given to the local government to reduce the corruption and rentseeking behavior of local officials. On the one hand, the fiscal decentralization is embedded in the administrative centralization system of Chinese fiscal decentralization system .On the other hand, the local government infrastructure system and the incentive and restraint mechanism have to be improved.

\section{References}

[1]Lei Xin, Gong Feng. The quantitative measure of the Chinese fiscal decentralization[J].Statistical research ,2010,10:47 -55.

[2]GongFeng, Lu Hongyou. Public expenditure structure, fiscal decentralization and preference[J].Management of the world,2009, 01:10 -21.

[3]Huang Junjie. The study of corruption on the background of fiscal decentralization in China[J]. Economic system reform ,2006,06:107 - 111.

[4]Lu Hongyou,GongFeng.The government competition, bandwagon effect and the benefit spillover of budget expenditure [J]. Management of the world ,2007,08:12 -22.

[5]He Lixin,PanChunyang, YuanCongshuai. Fiscal decentralization and official corruption -- an empirical study of based on the provincial panel data of 1999-2007 in China [J].The contemporary financial,2011,03:38- 46.

[6]Wu Yiping.Fiscal decentralization, corruption and governance [J].Economics (JiKan),2008, 04:1045 - 1060 .

[7] Alam,M,S (1989) "Anatomy of corruption : an Approch to the political Economy of underdevelopment ", the American journal of economy and sociology 48,n 4-441-456.

[8] anderson,T.L and P.J.HILL(1986) "Constraining the transfer society constitutional and moral dimensions " cato journal 6,n $1: 317-339$.

[9] associated press (2006),ivory coast wants Estonian tanker held AP Wire service (September 26 th) [10] Ayittey, G,B,N (1992).Africa betrayed .new York, St.Martin press.

[11] bayley , D.H.(1996)"THE Effects of corruption in developing nation" the western political quarterly 19,n $4: 719-732$

[12]BBC News (2004) "how deep is corruption in Africa "opinion survey "London England BBC News . 